\title{
European Journal of
}

\section{Health Sciences}

(EJHS)

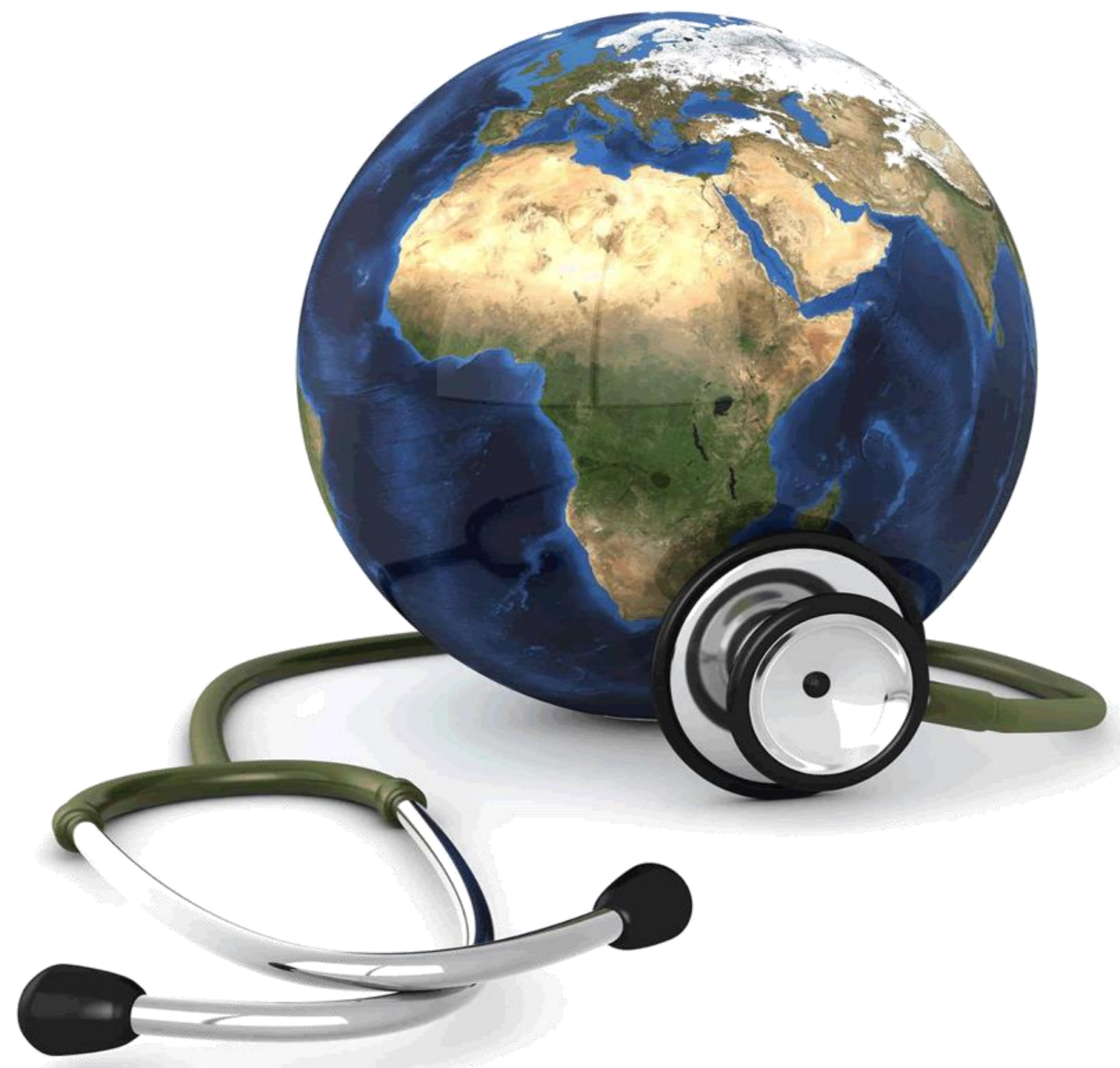

OBESITY: IMPROVING ACCESS TO FACILITIES FOR

EXERCISE AMONG FORMAL SECTOR EMPLOYEES IN KENYA

Joshua Ongwae

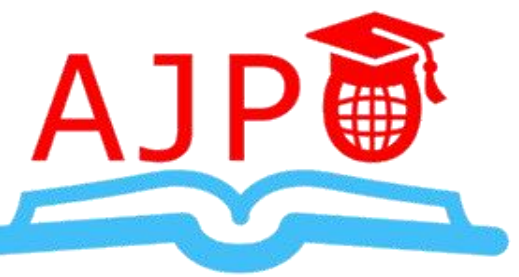




\title{
OBESITY: IMPROVING ACCESS TO FACILITIES FOR EXERCISE AMONG FORMAL SECTOR EMPLOYEES IN KENYA
}

\author{
Joshua Ongwae \\ Post Graduate Student: Kenyatta University \\ Author's E-mail: jomusa2000@yahoo.com
}

\begin{abstract}
Purpose: This systematic review addresses the challenges of lack of access to facilities for exercise among employees working in the formal sector in Kenya. It identifies the causes of the problem and summarizes the best available evidence of the most promising options to address the problem.

Methodology: A systematic approach was used in conducting literature review. The selection criteria for the papers were based on relevance of the paper and applicability to the context of study. At the initial stages, the investigations were limited to Pubmed and Hinari academic data bases for academic journals on the subject. When the databases did not yield adequate results, other search engines were used. Google and google scholar provided relevant articles. In order to get the best results which are relevant to the policy brief subject, terminologies and key words were used in the search. The following search terms were run in the two databases: 'Workplace Obesity', 'Obesity and exercise at the workplace', 'Physical Activity in the Workplace', Workplace and obesity' and 'workplace gyms'. A database was created in which the source of the literature identified and reference details of the search were stored. My search yielded 122 records of which 85 records remained after duplicates were removed. 60 records were screened and at the end 25 records were included in the final analysis.
\end{abstract}

Findings: Obesity can have a huge impact in workplaces because it affects employees' productivity. Ultimately, it affects the organizations' bottom-line. This policy brief acknowledges that both the employee and the employer have a role to play in promoting utilization and access to facilities for exercise at the workplace.

Unique contribution to theory, practice and policy: Employees need to have sufficient knowledge about the benefits of engaging in physical. The employer needs to put policies and systems in place to promote access to facilities for exercise at the workplace. Such systems should include appointing Wellness coordinators and sensitizing the Human Resources personnel of their organizations about the advantages of having healthy employees.

Keywords: Workplace, Wellness, Exercise, Gym, Obesity 


\subsection{INTRODUCTION}

\subsection{Global overview of obesity}

For the first time in global history and in the course of one generation, families can move from malnutrition based on under-nutrition to malnutrition based on over-nutrition (Neuroanth, 2011). Over-nutrition has led to obesity, which is a result of an energy imbalance brought about by either excessive food intake or physical inactivity (Hill et al., 2013). The World Health Organization (WHO) defines obesity as abnormal or excessive accumulation of fat that may harm health. The body mass index (BMI) is a simple index of weight for height that is used to classify individuals as either being in the right weight, overweight or obese (WHO, 2015). Obesity is problem in the developing world because that is where the impact of changing diets is most marked, where the rates of over-consumption and the greatest continuing toll of under-consumption is witnessed (ODI, 2014). Globally the percentage of adults who were overweight or obese grew from $23 \%$ in 1980 to $34 \%$ in 2008 , with a higher increase seen in the developing world. Here, people affected by obesity more than tripled from around 250 million people in 1980 to 904 million in 2008 (ODI, 2014). According to WHO (2014), at least 2.8 million people die each year in the world as a result of being overweight or obese. As a consequence of obesity, Non Communicable Diseases (NCDs) have become a major issue of concern in the world today. Obesity has been associated with the rising global incidence of non-communicable diseases including some cancers, diabetes, heart disease and strokes (ODI, 2014).

\subsection{The situation of obesity in Kenya}

The Kenya Demographic and Health Survey (KDHS) of 2009 showed that overweight and obesity is twice as high in urban areas as in rural areas (40\% compared to $20 \%)$ and increases with age, education, and wealth. Several factors can be used to explain the reason why obesity is lower in rural settings than in urban settings. Most people in rural areas are still consuming fresh traditional foods. In addition, life in rural areas requires that people are active and there are high chances of walking than in urban areas (Ojiambo, 2015). According to a study entitled 'Overweight and obesity in urban Africa: A problem of the rich or the poor?' carried out by Ziraba et al. (2009) women who were engaged in income generating activities were more likely to be overweight or obese. This pattern might be related to changing nutritional and lifestyle trends, with urban populations consuming more refined and energy-dense foods and having fewer opportunities for physical activities. Gender dimensions have also been highlighted on obesity. The KDHS (2009) concluded that, women in Nairobi are most likely to be overweight or obese $(41 \%)$. The national prevalence of obesity of women aged 15-49 years old in Kenya is 23\% (KDHS, 2009). According Hochschild (2012) our homes have been invaded by the pressures of work and workplaces have become our second homes. This has led to women spending more and more time in formal work environments and less time at home, doing housework.

\subsection{The problem of obesity in formal sector organizations}

Like the way young people take school, the workplace is very much associated with the adult world, filled with elements that promote health as well as elements that reduce it (Harvard, 2014). Businesses are always determined to push productivity and reduce costs which might affect their profits. The Business Dictionary (2015) defines, formal sector employees as those 
employees working in the formal sector which encompasses all jobs with normal hours and regular wages, and are recognized as income sources on which income taxes must be paid. Indeed, many formal sector companies both small and large are realizing that obesity prevention and workplace health promotion programs can have an excellent return on investment (Harvard, 2014). Certainly, the impact of obesity at the workplace cannot be overstated. Obesity, with its links to many NCDs, is a huge drain on individual as well as corporate health (Harvard, 2014). It can affect productivity, worsen mobility and morale, and increase healthcare claims, sick days, and occupational injuries (Harvard, 2014). A study conducted in the US and published in the American Journal of Health Promotion finds that, "on average, a morbidly obese employee costs an employer over $\$ 4,000$ more per year in health care and related costs than an employee who is of normal weight" (Nuys et al, 2014). The study also revealed that obese individuals who had conditions such as high blood pressure, diabetes, and high cholesterol incurred more costs than obese workers without these conditions (Nuys et al, 2014). Elsewhere, Andreyeva (2014) says that obese workers miss more work days, and those absences carry high costs at the state and national level. Obesity presents a double burden of diseases in Kenya and Africa at large.

\subsection{Clarifying the problem of obesity in Kenya}

Recent evidence indicates that overweight and obesity are increasing in sub-Saharan Africa, including Kenya, at a rate of 5\% per year on average (Mbochi et al., 2012). Hence it is predicted that there will be an accompanying surge in NCDs. The cost for treating NCDs is huge which gives people reasons to worry. Healthy Active Living and Obesity Research Group (HALORG) (2014) notes that most NCD's share the same risk factors; tobacco smoking, a diet high in saturated fat and low in fruit and vegetables, alcohol consumption and physical inactivity. Despite strong evidence of the arrival and consequences of the physical activity and nutrition transition in developing countries like Kenya, the action from policy-makers, international aid agencies, industry and academics to date has been almost absent (HALORG, 2014). Consequently, overweight, obesity and associated comorbidities are likely to be on the increase in Kenya and other developing countries.

Being overweight seems to predispose one to several NCDs including type 2 diabetes, hypertension, stroke, heart attack, congestive heart failure and several cancers (mainly colorectal and prostate) (Lokuruka, 2013). Most obese patients are observed to have decreased glucose tolerance, decreased sensitivity to insulin, decreased production of ketone bodies during starvation, and decreased sensitivity to growth hormones (Lokuruka, 2013).

Kyrou et al., (2014) state that mortality rates increase with increasing weight and obesity which leads to reduced life expectancy. When operated upon, obese patients are under increased risk of death when under anesthesia; surgical operations on them are difficult and are often accompanied by post-operative complications. Employees of the formal sector are regarded as being of high social class and most of them are in urban settings. Growing evidence points to some characteristics of the workplace itself as motivators of weight gain and obesity (Harvard, 2014). Globalization has come with it more sedentary jobs Zimmet \& Alberti (2012). Cultural attitudes to these jobs place them as more prestigious by many people in developing countries. Preventing obesity or working on addressing obesity is extremely important in averting a more serious health issue which might arise in future. According to the Kenya Institute of Management (KIM) (2010) the average office worker in 
Kenya spends at least eight hours per work day sitting at a desk. Outside the workplace, there are more hours of physical inactivity; commuting, watching television and sleeping. Attitudes towards exercise, lack of support, past failure, fatigue and concerns about the cost of paying for gym services discourages many people from becoming physically active (KIM, 2010).

\subsection{IDENTIFICATION AND ANALYSIS OF OPTIONS TO ADDRESS THE LACK OF ACCESS TO FACILITIES FOR EXERCISE FOR EMPLOYEES IN FORMAL EMPLOYMENT IN KENYA}

\subsection{Methods}

A systematic approach was used in conducting literature review. The selection criteria for the papers was based on relevance of the paper and applicability to the context of study. Use of a systematic approach was useful in informing the policy brief as it used rigorous scientific methods in assessing high quality literature in addressing the topic under investigation. At the initial stages, the investigations were limited to PubMed and Hinari academic data bases for academic journals on the subject. When the databases did not yield adequate results, other search engines were used. Google scholar provided relevant articles which were accessed free through Hinari database. A random search was also done using the google search engine to determine whether there are any articles with a local perspective of the desired information. In order to get the best results which are relevant to the policy brief subject, terminologies and key words were used in the search. The following search terms were run in the two databases: 'Workplace Obesity', 'Obesity and exercise at the workplace', 'Physical Activity in the Workplace', Workplace and obesity' and 'workplace gyms'. The search for all the terminologies produced ten articles each. Unfortunately, most of the articles were irrelevant to the study context. The studies which were included had to meet the criteria described below:

1. The articles were based on the workplace health

2. Reported key outcomes to measure the strategies for implementing the activities A database was created in which the source of the literature identified and reference details of the search were stored. The PRISMA diagram, databases used and decision taken on the applicability of the different articles evaluated tables are presented below. 


\section{PRISMA Diagram}

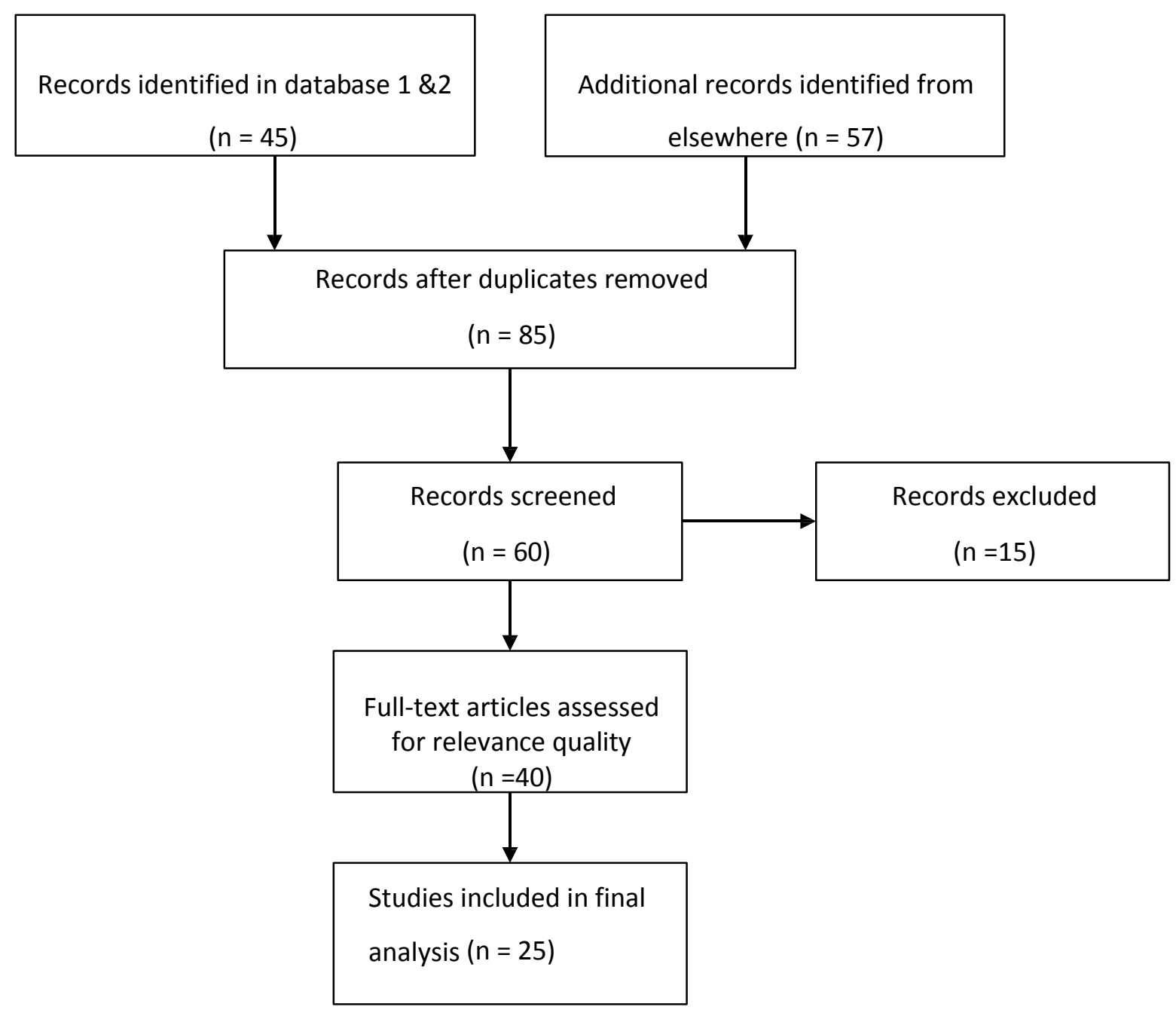




\section{Data Bases and search Terms Used in Identification of options}

\begin{tabular}{|c|c|c|}
\hline \multirow{7}{*}{\begin{tabular}{|l} 
Database \\
Pubmed
\end{tabular}} & Search Terms & Results \\
\hline & \multirow{4}{*}{$\begin{array}{l}\text { Workplace } \\
\text { Obesity }\end{array}$} & Addressing obesity in the workplace: The role of employers \\
\hline & & $\begin{array}{l}\text { Home and workplace built environment supports for physical } \\
\text { activity }\end{array}$ \\
\hline & & $\begin{array}{l}\text { Workplace Interventions to ReduceObesity and } \\
\text { Cardiometabolic Risk }\end{array}$ \\
\hline & & $\begin{array}{l}\text { The effectiveness of worksite nutrition and physical activity } \\
\text { interventions for controlling employee overweight and obesity: a } \\
\text { systematic review. }\end{array}$ \\
\hline & \multirow[t]{2}{*}{$\begin{array}{ll}\text { Obesity and } \\
\text { exercise at } & \text { th } \\
\text { workplace } & \end{array}$} & $\begin{array}{l}\text { Office-based physical activity and nutrition intervention: } \\
\text { barriers, enablers, and preferred strategies for workplace } \\
\text { obesity prevention, Perth, Western Australia, } 2012 \text {. }\end{array}$ \\
\hline & & $\begin{array}{l}\text { Outcomes and utilization of a low intensity workplace weight } \\
\text { loss program. }\end{array}$ \\
\hline \multirow[t]{4}{*}{ Hinari } & \multirow[t]{2}{*}{$\begin{array}{l}\text { "Workplace" } \\
\text { "obesity" }\end{array}$} & $\begin{array}{l}\text { Office-Based Physical Activity and Nutrition Intervention: } \\
\text { Barriers, Enablers, and Preferred Strategies for Workplace } \\
\text { Obesity Prevention, Perth, Western Australia, } 2012\end{array}$ \\
\hline & & $\begin{array}{l}\text { Obesity and workplace traumatic injury: does the science support } \\
\text { the link? }\end{array}$ \\
\hline & \multirow[t]{2}{*}{ Workplace Gym } & $\begin{array}{l}\text { Unraveling Exercise Addiction: The Role of Narcissism and } \\
\text { Self-Esteem }\end{array}$ \\
\hline & & $\begin{array}{l}\text { Are worksite interventions effective in increasing physical } \\
\text { activity? A systematic review and meta-analysis }\end{array}$ \\
\hline
\end{tabular}




\section{Appendix 4: Relevance Check and Applicability}

\begin{tabular}{|c|c|c|c|c|c|}
\hline Article & Relevance & $\begin{array}{l}\text { Applicability to } \\
\text { mv context }\end{array}$ & $\begin{array}{l}\text { Quality } \\
\text { assessment }\end{array}$ & Decision & $\begin{array}{ll}\text { Reason } & \text { for } \\
\text { reiection } & \end{array}$ \\
\hline $\begin{array}{l}\text { Heinen } \quad \& \\
\text { Darling }\end{array}$ & Accept & Accept & Accept & Accept & \\
\hline $\begin{array}{l}\text { Thorndike } \\
(2011)\end{array}$ & Accept & Accept & Accept & Accept & \\
\hline $\begin{array}{ll}\text { Anderson } & \text { et } \\
\text { al. (2009) } & \\
\end{array}$ & tAccept & Accept & Accept & Accept & \\
\hline Bond et & Accept & Reject & Accept & Reject & $\begin{array}{l}\text { The focus is in } \\
\text { children }\end{array}$ \\
\hline $\begin{array}{l}\text { Renaud et al. } \\
(2008)\end{array}$ & Accept & Reject & Accept & Reject & $\begin{array}{l}\text { It does not } \\
\text { focus on access } \\
\text { to facilities for }\end{array}$ \\
\hline $\begin{array}{ll}\text { Carpenter } & \text { et } \\
\text { al. (2014) } & \end{array}$ & Accept & Accept & Accept & Accept & \\
\hline $\begin{array}{l}\text { Bruno et al. } \\
(2014)\end{array}$ & Accept & Accept & Accept & Accept & \\
\hline
\end{tabular}

\subsection{Results}

Several records were identified from the literature search conducted. In total, eighty-five records were identified after removal of duplicates out of which forty records were screened of relevance. Twenty-five articles were included in this study. A number of options to improve access to facilities for exercise at the workplace were identified through a comprehensive literature search. The proposed options will produce results when employees have been sensitized and understand the need to engage in physical activities. Additionally, policy options discussed in this policy brief can be adopted independently or complementary to each other. Nevertheless, a systematic review by Thorndike (2011) concluded that there was insufficient evidence to determine the effectiveness of a single component worksite intervention that focused on nutrition, physical activity, or other behavioral intervention, but there was sufficient evidence to recommend interventions that combine both physical activity and nutrition components. The following options were picked for a discussion because they were the most mentioned options as I conducted the systematic review.

The options discussed are:

a) Sensitization, counselling and role modelling 
b) Health screening at the workplace

c) Making available onsite or subsidized gym facilities

d) Promoting and implementing workplace wellness programmes

\subsection{Policy Option One: Sensitization, Counselling and Role Modelling}

Sensitization and role modelling can enhance access to facilities for exercise. Regular health sensitization workshops should be held at various workplaces to raise awareness on the importance of maintaining the correct weight. All employees should receive health education information yearly (World Economic Forum, 2008). The sensitization workshops should raise awareness on the risk factors of most NCDs as well as strategies and benefits for maintaining the correct weight (The Bailey Group, 2014). Though the results of such workshops have been positive a systematic review by Marshall (2004) found out that theoretical or educational approaches alone were less effective than those that added behavioral counselling tailored to individual needs. There is also good evidence that intensive counselling (combined nutrition education with behavioral dietary counselling provided by a nutritionist, dietician, or specially trained primary care clinician) can produce meaningful behaviour change (Bruno et al, 2014). The sensitization should also include measures which the organizations have put in place to address the problem of access to facilities for engaging in physical activities at the workplace. For sensitization and behaviour change initiatives to be successful then individuals who are committed to a certain lifestyle are best placed to urge their colleagues to change. Heinen and Darling (2009) argue that at the workplace certain employers have the visibility to be role models and to influence change. Recruiting role models in addressing the challenge of access to facilities for engaging in physical activities will result in better participation in Wellness activities by employees. Wellness Champions of various organizations can be recruited to serve as champions for healthy lifestyles and make themselves available for questions and consultation on health and behaviour change factors (Heinen and Darling, 2009). Employees who are gym enthusiasts are best placed to promote participation in the gym among their colleagues. They will act as the support for other employees who want to utilize gym facilities. Having an exercise facility at the workplace level can have a huge impact on the health and wellbeing of employees. However, employers should move from raising awareness alone to putting down measures which can help employees to control their weight (The Bailey Group, 2014).

\subsection{Policy Option Two: Health Screening In the Workplace}

Organizing and promoting health screening camps at the workplace can have a huge impact on the health choices of employees (CDC, 2013). Health screening which offers individuals a chance to know whether they have particular diseases or conditions has been identified as one of the employee health promotion strategies. Preventive checkups are an essential part of health promotion efforts. Many preventive screenings are a cost-effective 


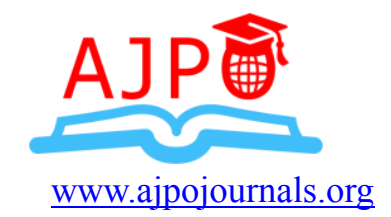

way to identify and treat potential health problems before they worsen (CDC, 2010). It is therefore cheaper to invest in preventive screenings for employees rather than to wait to treat a condition.

Body Mass Index (BMI) check is the easiest way to tell the weight status of an individual. It is calculated from a person's weight and height. Calculating BMI is one of the best methods for population assessment of overweight and obesity (CDC, 2014). After knowing the health status of individuals companies should devise a plan to address the principal risk factors (Heinen and Darling, 2009). Individuals are most likely to take action and address their weight status once a medical assessment has revealed that they are obese and the risk of their health status communicated to them. Screening will therefore assist individuals to know where they are in regard to their health and assist them to set targets to address the various health conditions. For the individuals who are obese they will attend counselling and seek guidance on how best to reduce their weight.

\subsection{Policy Option Three: Availability of Onsite or Subsidized Gym Facilities}

Onsite and subsidized gyms can be a solution to the challenge of access to facilities for exercise. The pressures of work and the long hours which employees are working make it difficult for them to engage in physical activities outside the workplace. In addition, traffic congestion which is a characteristic feature of most Kenyan roads has made it difficult for employees to access places where they can exercise. The exorbitant fees charged by gyms has also put away those employees who want to exercise. Bruno et al. (2014) argues that exercise is an important part of physical activity that is planned, structured, and repetitive with the aim of improving or maintaining one or more components of physical fitness. Due to this challenge it is therefore sensible to initiate gyms at the workplaces or subside for employees to attend gyms located near their workplaces. Pridham (2002) notes that employee fitness centers are one of the top three amenities requested by employees in the US.

In addition, with the long hours spent at work, the worksite is a good location for fitness routines and weight management programs (Heinen and Darling, 2009). It is such facilities which attract and act as a major retention tool for employees (Pridham, 2002). The benefits for such facilities include improved cognition/memory, selfconfidence, job satisfaction, ability to cope with stress, psychosocial well-being and increased likelihood of meeting daily physical activity recommendations (Curry, 2012). Indeed, regular physical activity plays a lead role in health promotion and in disease prevention (Bruno et al, 2014). Physical activity is still an important part of weight loss programmes as it is critical for weight loss maintenance, improves overall health and wellbeing, and plays a role in preserving lean body mass during weight loss (Carpenter et al., 2014).

In order to promote participation in exercises in the workplace, employers have found that they can turn some extra space into an office gym with great results (Dalrymple, 2012). 


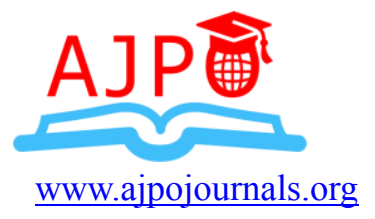

Employers can purchase few relevant equipment which they can put in a room for employees to use in exercising. The room can be installed with showers to encourage employees to exercise during breaks. Other essential facilities can also be made available to encourage employees to participate in the gym. Heinen and Darling (2009) have noted that an onsite child care provided at its fitness centers to make it easier for employees with young children to exercise encourages participation in physical exercises. It will also be beneficial to open the gates of an onsite gym to other registered immediate family members (Heinen and Darling (2009).

\subsection{CONCLUSION AND RECOMMENDATIONS}

Obesity is a global problem which has adverse effects on communities. In developing countries, the cause of obesity is linked to globalization and westernization. Obesity can have a huge impact in workplaces because it affects employees' productivity. Ultimately, it affects the organizations' bottom-line. This policy brief acknowledges that both the employee and the employer have a role to play in promoting utilization and access to facilities for exercise at the workplace. Employees need to have sufficient knowledge about the benefits of engaging in physical activity as well as be ready to know their health status for them to take specific action. The employer needs to put systems in place to promote access to facilities for exercise at the workplace. Such systems should include appointing Wellness coordinators and sensitizing the Human Resources personnel of their organizations about the advantages of having healthy employees. Additionally, those with the responsibility of implementing workplace wellness programmes should be recognized, motivated and given clear terms of reference by the management of their organizations. Finally, healthy employees are likely to be happy and more productive. They are also more likely to perform better when they know that their companies value their contribution by investing in their well-being.

\section{References}

Abraham, C. \& Graham-Rowe, E. (2009). Are worksite interventions effective in increasing physical activity? A systematic review and meta-analysis: Available from:

http://hinarilogin.research4life.org/uniquesigwww.tandfonline.com/uniquesig0/doi /pdf/10.1080/17437190903151096 (Accessed 19/01/2015)

Anderson et al. (2009). The effectiveness of worksite nutrition and physical activity interventions for controlling employee overweight and obesity: a s ys te maticreview.Availablef rom: http://www.ncbi.nlm.nih.gov/pubmed/19765507/ (Accessed 06/01/2015) 


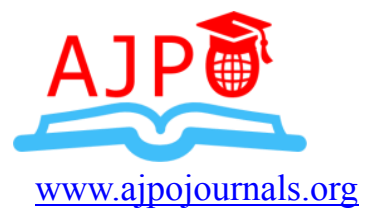

Bahaudin, M. and Cavico, F. (2013). Corporate Wellness Programs: Implementation Challenges in the Modern American Workplace. Available from: http://www.ncbi.nlm.nih.gov/pmc/articles/PMC3937880/ (accessed on 24/03/2015)

Birdee, GS., Byrne DW., McGown PW., Rothman RL., Rolando LA., Holmes MC, Yarbrough, MI. (2013). Relationship between physical inactivity and health characteristics among participants in an employee-wellness program. Available from; http://www.ncbi.nlm.nih.gov/pubmed/23618884 (accessed on 24/03/2015

Blackford, K Jancey., J, Howat., P, Ledger, M and Lee. (2012) Office-Based Physical Activity and Nutrition Intervention: Barriers, Enablers, and Preferred Strategies for WorkplaceObesity.Available from; http://www.cdc.gov/pcd/issues/2013/13 0029.htm. (Accessed 12/01/2015)

Business Dictionary. (2015). Formal Sector. Available from; http://www.businessdictionary.com/definition/formal-sector.html (Accessed 28/05/2015)

Busum KV., Mattke S. (2013). Financial incentives: only one piece of the workplace wellness puzzle comment on "corporate wellness programs: implementation challenges in the modern american workplace". Available from; http://www.ncbi.nlm.nih.gov/pubmed/24596890 (Accessed 29/03/2015)

CDC. (2011). Physical Activity for a Healthy Weight. Available from: http://www.cdc.gov/healthyweight/physical_activity/index.html?s_cid=govD_dnp ao_006 (Accessed 28/11/2014)

CDC. (2013). Workplace Health Promotion. Available From:

Christensen, D, Eis, J, Hansen, A, Larsson, M, Mwaniki, D, Kilonzo, B, Tetens, I, Boit, M, Kaduka, L, Johnsen, K, \& Friis, H. (2008). Obesity and regional fat distribution in Kenyan populations: Impact of ethnicity and urbanization. Annals of Human Biology, March-April 2008; 35(2): 232-249

Cook, S. (2013). Fighting Non-Communicable Diseases in Kenya: Why Food Policy Remains Untried. Masters Thesis. Available from: http://rudar.ruc.dk/bitstream/1800/12826/1/Thesis\%20-\%20Summer\%20Cook.pdf (Accessed 29/11/2014)

Curry, R. (2012). Workplace Physical Activity: A Review of Literature Examining Policy and Environmental Approaches. Available from: http://www.hamilton.ca/NR/rdonlyres/79F8F671- B240-4B9F-99EB3DE3901D58BD/0/Literature_review_FINAL.pdf (Accessed 06/01/2015) 


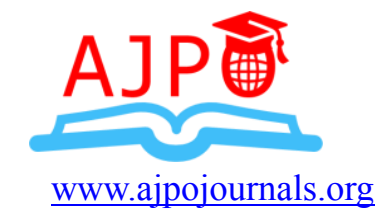

Dalrymple, J. (2012). Office Gyms: The Benefits, The Legalities. Available from: http://www.lynchburgbusinessmag.com/office-gyms-thebenefits-the-legalities/ (Accessed 07/07/2015)

Devaux, Marion, et al. (2011). "Exploring the Relationship Between Education and Obesity", OECD Journal: Economic Studies, Vol.2011/1.Available from: http://dx.doi.org/10.1787/eco_studies-2011-5kg5825v1k23 (accessed 28/11/2014)

Dickson-Swift, V., Fox, C., Marshall, K., Welch, N., Willis, J. (2014). "What really improves employee health and wellbeing: Findings from regional Australian workplaces", International Journal of Workplace Health Management, Vol. 7 Iss: 3 , pp. $138-155$

Dodson, E., Lovegreen, S., Elliott, M., Haire-Joshu, D., and Brownson, R. (2008). Worksite Policies and Environments Supporting Physical Activity in Midwestern Communities. Available from;

http://hinarilogin.research4life.org/uniquesigwww.ncbi.nlm.nih.gov/uniquesig0/p mc/articles/PMC3973737/ (Accessed 27/03/2015)

Duque-Páramo, M. (2003). Biomedical and Sociocultural Factors in Obesity in Children. University of South Florida. Available from:

Geoffrey, S. \& Kim, M. (2015). Journal article writing International Journal of Entrepreneurship and Project Management. Vol. 1.Issue 1(1). pp 1-13

Goetzel, R., Roemer, E., Liss-Levinson, R., Samoly, D. (2008). Workplace Health Promotion: Policy Recommendations that Encourage Employers to Support Health Improvement Programs for their Workers. Partnership for Prevention. Available from: https://www.prevent.org/data/files/initiatives/workplacehealtpromotionpolicyrecommendations.pdf (Accessed 20/01/2015)

Hannon, P., Garson, G., Harris, J., Hammerback, K., Sopher, C., and Clegg-Thorp, C. (2012). Workplace Health Promotion Implementation, Readiness, and Capacity Among Mid-Sized Employers in Low-Wage Industries: A National Survey. From; http://hinarilogin.research4life.org/uniquesigwww.ncbi.nlm.nih.gov/uniquesig0/p mc/articles/PMC3493879/ (Accessed 30/03/2015)

Harvard. (2014). Worksite Obesity Prevention Recommendations: Complete List (Online). Available From: Http://Www.Hsph.Harvard.Edu/Obesity-PreventionSource/Obesity-Prevention/Worksites/Worksites-Obesity-PreventionRecommendations-Complete-List/ (Accessed 18/11/2014) 
Heinen, L., and Darling, H. (2009). Addressing obesity in the workplace: the role of employers.Availablefrom: http://www.ncbi.nlm.nih.gov/pmc/articles/PMC2879173/ (Accessed on 05/01/2015)

Hill, J. O. , Wyatt, H. R. , and Peters, J. C. (2013). Energy Balance and Obesity. Available from: http://www.ncbi.nlm.nih.gov/pmc/articles/PMC3401553/ (Accessed 21/11/2014)

Hochschild, A. (2012). The Time Bind. Available from; http://onlinelibrary.wiley.com/doi/10.1111/j.1743-4580.1997.tb00019.x/abstract (Accessed 01/05/2015)

http://www.academia.edu/467163/Biomedical_and_sociocultural_factors_in_obesity_in_ children (Accessed 7/01/2014)

http://www.cdc.gov/workplacehealthpromotion/implementation/topics/physicalactivity.html (Accessed 10/04/2015)

Ibrahim et al. (2013). Perceived physical activity barriers related to body weight status and sociodemographic factors among Malaysian men in Klang Valley. BMC Public Health. Available from; http://www.biomedcentral.com/1471-2458/13/275 (accessed on 22/03/2015)

Kaduka, L., Kombe, Y., Kenya, E., Kuria, E., Bore, J., Bukania, Z, Mwangi, M. (2012). Prevalence of Metabolic Syndrome Among an Urban Population in Kenya. Available from; http://care.diabetesjournals.org/content/35/4/887.short (Accessed $5 / 04 / 2015)$

Karen Van Nuys., Denise Globe., Daisy Ng-Mak., Hoiwan Cheung., Jeff Sullivan, Dana Goldman. The Association Between Employee Obesity and Employer Costs: Evidence From a Panel of U.S. Employers. American Journal of Health Promotion, 2014; 28 (5): 277 DOI: 10.4278/ajhp.120905-QUAN-428 Kenya National Bureau of Statistics (KNBS) and ICF Macro: Kenya Demographic and Health Survey 2008-09. Calverton, Maryland: KNBS and ICF Macro; 2010.

KIM. (2014). Office Obesity. Available from: http://www.kim.ac.ke/managementmagazine/article/1364909965/office-obesity-unmasked (Accessed 29/11/2014)

Kyrou, I, Randeva, Hs, Weickert. (2014). Clinical Problems Caused By Obesity. Available From; http://hinarilogin.research4life.org/uniquesigstatic.pubmed.gov/uniquesig0/pubme d/25905207 (ACCESSED 29/04/2015) 


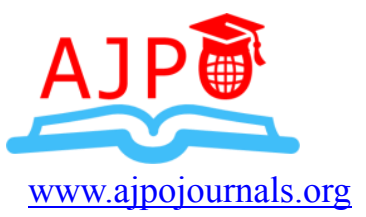

Leigh, M. (2015). Demand Media: Perils of Workout Equipment in the Workplace. Available from: http://work.chron.com/perils-workout-equipment-workplace15876.html (Accessed 23/03/2015)

Leslie JH., Braun KL., Novotny R., Mokuau N. (2013). Factors affecting healthy eating and physical activity behaviors among multiethnic blue- and white-collar workers: a case study of one healthcare institution. Available from: http://hinarilogin.research4life.org/uniquesigwww.ncbi.nlm.nih.gov/uniquesig0/p ubmed/?term=Leslie $+\mathrm{JH} \% 2 \mathrm{C}+\mathrm{Braun}+\mathrm{KL} \% 2 \mathrm{C}+$ Novotny $+\mathrm{R} \% 2 \mathrm{C}+\mathrm{Mokuau}+\mathrm{N}$ (Accessed 1/05/2015)

Lovell, G., Ansari, W., Parker, J. (2010). Perceived Exercise Benefits and Barriers of Non-Exercising Female University Students in the United Kingdom. Available from: http://www.ncbi.nlm.nih.gov/pmc/articles/PMC2872307/ (Accessed 29/04/2015)

Marshall, L. (2004). Challenges and opportunities for promoting physical activity in the workplace. Available from; http://www.sciencedirect.com/science/article/pii/S1440244004802792 (Accessed 25/03/2015)

Mattke, S., Schnyer, C., Busum, K. (2012) A Review of the U.S. Workplace Wellness Market.Availablefrom; http://www.dol.gov/ebsa/pdf/workplacewellnessmarketreview2012.pdf (Accessed 01/05/15).

Mbochi, R, Kuria, E, Kimiywe, J, Ochola, S And Steyn, P. (2012) Predictors Of Overweight And Obesity In Adult Women In Nairobi Province, Kenya. Available From: Http://Www.Biomedcentral.Com/1471-2458/12/823 (Accessed 29/11/2014)

McNeill, L., Stoddard, A., Bennett, G., Wolin, K., and Sorensen, G. (2012). Influence of individual and social contextual factors on changes in leisure-time physical activity in working-class populations: results of the Healthy Directions-Small Businesses Study. Available from; http://www.ncbi.nlm.nih.gov/pmc/articles/PMC3652385/ (accessed 26/2015)

Meda L. (2013) Assessing factors influencing university students to uptake voluntary counselling and testing (VCT) of human immune deficiency virus/acquired immune deficiencysyndrome(HIV/AIDS).Availablefrom: http://www.academicjournals.org/article/article1379689045_Meda.pdf (Accessed 28 January 2015) 
Mitchell MS., Goodman JM., Alter DA., John LK., Oh PI., Pakosh MT., Faulkner GE. (2013). Financial incentives for exercise adherence in adults: systematic review and meta-analysis.Availablefrom; http://hinarilogin.research4life.org/uniquesigwww.ncbi.nlm.nih.gov/uniquesig0/p ubmed/24139781 (Accessed on 19/03/2015)

Morgan, L. (2015). Perils of Workout Equipment in the Workplace. Demand Media. Available from; http://work.chron.com/perils-workout-equipment-workplace15876.html (Accessed on 21/03/2015)

Mujtaba, B., and Cavico, F. (2013). Corporate Wellness Programs: Implementation Challenges in the Modern American Workplace. Available from; http://www.ncbi.nlm.nih.gov/pmc/articles/PMC3937880/ (Accessed on 18/03/2015)

Nelson, C., Wagner, G., Caban-Martinez, A., Buxton, O., Kenwood, C., Sabbath, E., Hashimoto, D., Hopcia, K., Allen, J., and Sorensen, G,. (2014). Physical Activity and Body Mass Index:The Contribution of Age and Workplace Characteristics. Available from; http://hinarilogin.research4life.org/uniquesigwww.ncbi.nlm.nih.gov/uniquesig0/p mc/articles/PMC4007484/ (accessed 29/03/2015)

Neuroanth. (2011). The Anthropology Of Obesity. Available From:

Http://Blogs.Plos.Org/Neuroanthropology/2011/04/12/The-Anthropology-OfObesity/ (Accessed 05/11/2014)

Newman, L., Stinson, K., Metcalf, D., Fang, H., Brockbank, C., Jinnett, K., Reynolds, S., Trotter, M., Witter, R., ,Atherly, A., and Goetzel, R. (2015). Implementation of a Worksite Wellness Program Targeting Small Businesses:The Pinnacol Assurance Health Risk Management Study. Available from; http://hinarilogin.research4life.org/uniquesigwww.ncbi.nlm.nih.gov/uniquesig0/p mc/articles/PMC4274320/ (Accessed 21/03/2015)

Oberlinner C., Lang S., Germann C., Trauth B., Eberle F., Pluto R., Neumann S., Zober A. (2007). Prevention of overweight and obesity in the workplace. BASF-health promotion campaign "trim down the pounds--losing weight without losing your mind". Accessed from: http://www.ncbi.nlm.nih.gov/pubmed/17701837 (Accessed 06/01/2015)

Ojiambo, R. (2015). Are Lifestyle Shifts Fuelling The Obesity Epidemic In Urbanised Africans?AvailableFrom; Http://Hinarilogin.Research4life.Org/Uniquesigstatic.Pubmed.Gov/Uniquesig0/Pu bmed/25921431 (Accessed 30/04/2015) 
Overseas Development Institute (ODI). (2014). Future diets: Implications for agriculture and food prices. Available from: http://www.odi.org/sites/odi.org.uk/files/odiassets/publications-opinion-files/8776.pdf (Accessed 20/11/2014)

Pollack, K. and Cheskin, L. (2007). Obesity and workplace traumatic injury: does the science support the link? Available from; http://www.ncbi.nlm.nih.gov/pmc/articles/PMC2610625/ (Accessed 23/04/2015)

Prevention, Perth, Western Australia, 2012. Available from; http://www.ncbi.nlm.nih.gov/pmc/articles/PMC3775360/ (Accessed 20/04/2015)

Pridham, S. (2002). Workplace Fitness Facilities: a popular amenity with a healthy payback. Available from: http://www2.trifit.com/articles/OfficeLifeArticle.pdf (Accessed 7/01/2015)

Summer, C. (2013). Fighting Non-Communicable Diseases in Kenya: Why Food Policy Remains Untried. Available from; http://www.rucsdigitaleprojektbibliotek.dk/handle/1800/12826 (Accessed $(30 / 04 / 2015)$

Tate DF., Wing RR., Winett RA. (2001). Using Internet technology to deliver a behavioral weightlossprogram.Availablefrom: http://www.ncbi.nlm.nih.gov/pubmed/11231746/ (Accessed 06/01/2015)

Tatiana Andreyeva., Joerg Luedicke, Y. Claire Wang. State-Level Estimates of ObesityAttributable Costs of Absenteeism. Journal of Occupational and Environmental Medicine, 2014; 56 (11): 1120 DOI: 10.1097/JOM.0000000000000298The Standard Newspaper. (2011) Half of Kenya's women obese, medics warn. Availablefrom: http://www.standardmedia.co.ke/?articleID=2000041353\&pageNo=1. (Accessed 23/07/2013)

The Bailey Group. (2014). Addressing Obesity through Your Workplace Wellness Program. Available from: https://www.mbaileygroup.com/blog/workplacewellness/addressing-obesity- workplace-wellness-program/ (Accessed 03/10/2015)

The Cochrane Library. (2014). About Cochrane Systematic Reviews and Protocols. Available From: http://www.thecochranelibrary.com/view/0/AboutCochraneSystematicReviews.ht $\mathrm{ml}$ (Accessed 18/01/2015) 
Thorndike, A. (2011). Workplace Interventions to Reduce Obesity and Cardiometabolic Risk.Availablefrom:http://www.ncbi.nlm.nih.gov/pmc/articles/PMC3374841/\#R2 3 (Accessed 05/01/2015)

Voa. (2009). Western-Style Diet Brings New Health Problems To Kenya. Available From: Http://Www.Voanews.Com/Content/Western-Style-Diet-Brings-NewHealth-Problems-To-Kenya-79929152/416643.Html (Accessed 29/11/2014)

Walraven, G. (2011). Health and Poverty: Global Health Problems and Solutions. London: Earthscan

WHO. (2013). Obesity and Overweight (Online). Who. Available From: Http://Www.Who.Int/Mediacentre/Factsheets/Fs311/En/ (Accessed 20/07/2013)

WHO. (2014). Global Health Observatory (GHO) Obesity. Available from: http://www.who.int/gho/ncd/risk_factors/obesity_text/en/ (Accessed 20/11/2014)

World Economic Forum. (2008). Working towards Wellness: Global Example

World Health Organization. (Who). (2013) Non Communicable Diseases (Online). Http://Www.Who.Int/Mediacentre/Factsheets/Fs355/En/ Who. Available From: (Accessed 16/10/2014)

Zimmet P, and Alberti, G. (2012). Introduction: Globalization and the Noncommunicable DiseaseEpidemic.Availablefrom; http://onlinelibrary.wiley.com/doi/10.1038/oby.2006.1/full (Accessed 20/04/2015)

Ziraba A, Fotso, J and Ochako, R. (2009). Overweight and obesity in urban Africa: A problem of the rich or the poor? Available from: http://www.biomedcentral.com/1471-2458/9/465 (Accessed 29/11/2014) 